\section{AS PAISAGENS CREPUSCULARES DA FICÇÃO CIENTÍFICA: A ELEGIA DAS UTOPIAS URBANAS DO MODERNISMO}

Jorge Luiz Barbosa. Niterói: Editora da UFF, 2013.

Pedro Paulo Pinto Maia Filho

Geógrafo; doutorando em Geografia pela Universidade Federal Fluminense (UFF), Brasil.

E-mail:pppmff@gmail.com.

As paisagens crepusculares da fiç̧âo cientifica: a elegia das utopias urbanas do modernismo de Jorge Luiz Barbosa reúne ensaios procedentes de sua tese de doutoramento, mas aqui sob um novo formato com o objetivo de ampliar o diálogo interdisciplinar e com um público leitor não necessariamente acadêmico.

O tema do estudo é a metrópole, interpretada por meio de suas projeçóes futuras concebidas pelos filmes de ficção científica. A grande metrópole é tema recorrente nos filmes do gênero sci-fi que partindo das cidades em que os produtores estavam inseridos indagam a forma de ser/estar no urbano.

O diálogo entre a geografia e a arte talvez seja uma das maiores contribuiçóes trazidas pela obra. Ao escolher as metrópoles futuristas do cinema de ficção científica para compreender a questão urbana na contemporaneidade, o autor percorre um campo pouco explorado pelos geógrafos, estabelecendo a possibilidade de inquirir o real através das representaçôes artísticas. A arte é tomada enquanto atividade criadora e produtora de sentido e passível de interpretação pela geografia.

Para entender a metrópole e a sociedade urbana pelo viés espacial elege-se o conceito paisagem, que se estabelece como fio condutor na leitura fílmica. Além de recurso metodológico a paisagem vai ser o conceito que permite a aproximaçáo da ciência geográfica com a arte cinematográfica, já que o sentido de "paisagem" nasce no campo das artes e só depois é apropriado como conceito científico.

O livro é dividido em quatro capítulos, que esmiúçam as metrópoles futuristas apresentadas em quatro filmes por ordem de seus lançamentos: Metrópolis (1924), Alphaville (1965), Blade Runner
(1982) e The Matrix (1999). As obras são eleitas pelo autor como representantes de diferentes períodos na elaboração de propostas de cidades ideias e modernistas, tais filmes recorrem à metrópole do amanhã como espaço narrativo onde se desenvolvem as tramas.

Os capítulos parecem seguir preceitos metodológicos que são recorrentes na interpretação fílmica realizada por Barbosa. Primeiramente os filmes são decompostos em seus contextos espaciais e temporais, analisa-se a influência dos movimentos artísticos contemporâneos à produção do filme (prática estética) e também dos princípios arquitetônicos, urbanísticos, econômicos e sociais (prática histórica). Tais práticas são apresentadas como formas de compreender as conjunturas de distintas cidades e em diferentes épocas. As metrópoles ficcionais são inspiradas em cidades "reais", manifestaçôes artísticas oriundas da literatura, pintura e das instalações artísticas assim como os novos traçados urbanos e novas formas arquitetônicas influenciam a paisagem representada na tela do cinema.

O entendimento das noçóes técnicas das produçôes cinematográficas é crucial na elaboração do argumento do texto. Roteiro, enquadramento, planos, personagem, utilização das imagens e dos diálogos são levados em consideração e alternamse com a prática estética e com a prática histórica para desvendar a metrópole através das paisagens simuladas pelas obras.

Para desenvolver sua leitura do clássico da ficção científica dirigido por Fritz Lang Metrópolis, o autor apresenta o pano de fundo ao qual o filme faz referência. Os movimentos artísticos de vanguarda de meados de 1910 como o "futurismo", "neoplasticismo" e o "cubismo" que se caracterizavam principalmente pela ruptura dos preceitos das artes "clássicas" e buscavam desenvolver a arte condizente com o mundo moderno e mecânico trazido pelo advento tecnológico do final do século XIX. A representação fílmica se apropria desses preceitos das vanguardas modernistas ao apresentar uma paisagem-imagem de uma metrópole monumental dominada por dispositivos técnicos, tais imagens não são meras opções de estilo, elas exprimem as mudanças na forma como a sociedade se relaciona com o espaço. A experiência humana se restringe 
ao trabalho e o movimento do corpo passa a ser mecanizado.

Muitos filmes de ficção científica se consolidam em transpor para a tela futuros distópicos. No filme de Jean-Luc Godard a cidade de Alphaville desponta na tela como uma metrópole moderna, com altos edifícios luminosos e largas avenidas, atributos similares aos dos projetos urbanísticos modernistas que estavam em ascensão na Europa. As racionalizaçóes do traçado espacial e das formas arquitetônicas estáo transpostas nos atos e comportamentos da populaçáo de Alphaville, condicionada a diversos padróes de conduta impostos por um supercomputador, dirigente máximo da cidade. Como na obra de Lang percebese uma forte relação entre o comportamento e ações do homem e a estruturação do espaço urbano.

Essa mesma racionalidade do urbanismo moderno de Le Corbusier vai se exibir de outra forma no futuro elaborado por Ridley Scott. Na Los Angeles futurista a exuberância da paisagem moderna convive com o abandono, a publicidade extenuante, o lixo e a multidão. A paisagem apocalíptica oferecida em Blade Runner parece fazer coro às criticas do modelo urbanístico modernista.

Em The Matrix dos irmãos Wachowski, a metrópole contemporânea apresentada em tela parece afinada com as representaçóes artísticas dos anos 1990, (exemplificado pelo autor nas obras Pizza City e Urbano com hipopótamo) onde o urbano é representado através das paisagens-imagens do caos, da desordem, e da barbárie. Porém a cidade oferecida pelo filme não é "real". Trata-se de uma metrópole simulada como paisagem digital. Uma representação inserida em uma representação.

O mesmo processo urbano-industrial que transforma a paisagem em escala mundial permitiu ao homem moderno, portar um dispositivo técnico que permite transpor em imagem (por que não em paisagens) suas inquietaçóes. O cinema já nasce apontando suas câmeras para grande cidade, que passa a ser o cenário privilegiado nas construçóes narrativas ficcionais. Ao mesmo tempo é na cidade que se encontra o grande público dessa nova forma de arte, o cinema desponta como arte destinada às grandes massas, estas passam a se (re)conhecer enquanto "homem urbano" na grande tela.

Trata-se de um importante trabalho que póe que evidência a arte como forma de entendimento do mundo, não se trata de mera representaçáo do real, mas sim de uma atividade criadora de novas realidades. Jorge Luiz Barbosa apresenta em seu livro quadro cidades do futuro elaboradas em diferentes contextos sócio-espaciais. São obras que carregam muitas similitudes entre si, o domínio da mecanização, da inteligência artificial, da monumental paisagem urbana inseridas em sistemas opressores. Tais elementos apontam para uma leitura negativa da metrópole do amanhá. Porém a utopia resite na forma de seus protagonistas que buscam romper com o estado de coisas, a possibilidade de mudança é permitida. A conflitividade exposta na paisagem cinematográfica reflete as mediaçóes espaçotemporais desenvolvidas na análise crítica dos modelos urbanos dominantes. 